\title{
豚ふん堆肥脱臭の可能性とオガクズ混合による 脱臭能力の向上
}

\author{
坂井隆宏・河原弘文・式町秀明 \\ 佐賀県畜産試験場, 佐賀県武雄市山内町, 849-2305 \\ (2007 年 3 月 12 日受付, 2007 年 5 月 7 日受理)
}

\begin{abstract}
緒
$\overline{\overline{\bar{一}}}$

堆肥は臭気成分を吸着する性質を持つことが知 られていることから，堆肥を利用した臭気低減技 術についてはすでにいくつかの研究事例 ${ }^{1-4)}$ があ る。特に田中ら ${ }^{4)}$ はオガクズ牛ふん堆肥に牛ふん 発酵時の臭気を吸着させることによって約 $95 \%$ のアンモニアと $40 \%$ の硫黄化合物を除去できた としている。この堆肥脱臭は農家が豊富に保有す る資材を利用した脱臭法であり, 脱臭装置の低コ スト化を可能とする技術であると思われるが，牛 ふん堆肥を養豚場に持ち込むことは防疫対策上望 ましくないため, 養豚農家には豚ふん堆肥を利用 した堆肥脱臭の技術が必要となる。そこで，本実 験では室内実験により豚ふん堆肥脱臭の可能性に ついて基礎的検討を行った。また, 既往の研究の 中で田中ら ${ }^{1)}$ は豚ふん堆肥では硫化メチルがほと んど除去できなかったとしていることから，豚ふ ん堆肥で堆肥脱臭を行う場合には何らかの処理を 施して臭気吸着能を高める必要がある。そこで, 臭気成分を物理的に吸着する能力を持つオガク ズ5) の混合による豚ふん堆肥の脱臭能力の向上に ついて検討を行った。
\end{abstract}

\section{材料および方法}

VP125 の塩ビパイプ, 3 L 三角フラスコ, エアー
ポンプ, ニードルバルブ付きフロート式流量計 (KOFLOC 社製)，シリコンチューブなどを利用 して実験脱臭槽を作成した。これは塩ビパイプを 脱臭槽とし, エアーポンプからの送気がニードル バルブ付きフロート式流量計を経て三角フラスコ 内に通じ, その後で塩ビパイプの脱臭槽の底部か ら通気し, 排気が塩ビパイプの上方から排出され る構造とした。また, エアーポンプの通気の途中 に分岐配管とエアー抜きのバルブを取り付け，バ ルブによって余分な通気を抜き，ニードルバルブ 付きフロート式流量計で通気量の微調整を行っ た。下記の試験区分を設定して実験を行った。

- 堆肥区: 豚ふん堆肥 $5.00 \mathrm{~kg}$ に $0.5 \mathrm{~L}$ 加水して 脱臭槽に充填。

・堆肥十オガクズ区 : 豚ふん堆肥 $2.5 \mathrm{~kg}$ にオガク ズを $2.5 \mathrm{~kg}$ 混合して $1.5 \mathrm{~L}$ 加水して脱臭槽に充 填。

加水は水分条件を合わせるために行った。豚ふ ん堆肥は定期的に切り返しを行い, 堆肥化開始か ら 2 ヶ月程度経過して水分が $33 \%$ 程度になった あのを使用した。また，この時使用したオガクズ の水分は $14.5 \%$ であった。臭気発生源としてアン モニアと硫黄化合物を同時に発生させるために採 卵鶏ふんを使用し，3L の三角フラスコに $1 \mathrm{~kg} の$ 鷄ふんと高濃度にアンモニアを発生させるための 濃アンモニア水 $10 \mathrm{~mL}$ を入れ, エアーポンプで 6

The Practicability of Swine Manure Compost Deodorization, and Effect of Mixed Sawdust to Odor Removal

Takahiro SAKaI, Hirofumi Kawahara and Hideaki SHIKImachi

Saga Prefectural Livestock Experiment Station, Yamauchi-cho, Takeo-shi, Saga, 849-2305

Key words : swine compost deodorization, sawdust

連絡先 : 坂井隆宏（E-mail : sakai-takahiro@pref.saga.lg.jp Tel. 0954-45-2030) 
$\pm 0.1 \mathrm{~L} / \mathrm{min}$ で三角フラスコ内に通気を行い, 鶏 ふん臭気とアンモニアの混合ガスを 1 週間に 1 回 フラスコ内容物を交換しながら室温条件下で両試 験区の脱臭槽に 3 週間通気した。

実験装置の脱臭槽を通過する前後の臭気を採取 し, アンモニアと硫黄化合物（硫化水素, メチル メルカプタン, 硫化メチル, 二硫化メチル）を測 定した。アンモニアは北川式ガス検知管を用いて 1 週間に 3 回の割合で測定した。硫黄化合物は常 法 ${ }^{6)}$ に準じてテドラーバッグに採取した臭気サン プルを FPD 付きガスクロマトグラフィー（島津 社製 GC-17A）を用いて 1 週間に 2 回測定した。 実験の開始時と終了時で各試験区の脱臭資材のア ンモニア態窒素 $\left(\mathrm{NH}_{4}-\mathrm{N}\right)$, 硝酸態窒素 $\left(\mathrm{NO}_{3}-\mathrm{N}\right)$, 水分, $\mathrm{pH}, \mathrm{EC}$ を測定した。測定法は常法7) に準じ た。

\section{結果}

各臭気成分の除去率を表 1 に示す。臭気非検出 の場合は $0 \mathrm{ppm}$ として除去率を計算した。硫化 水素に連続的な発生は見られず，突発的に低濃度 しか発生しなかっため表には掲載していない。ア ンモニアについては試験区間で除去率はほとんど 差はなく，ほぼ100\% 除去された。硫黄化合物に ついてはオガクズの混合によって除去率が上昇 し, 特に硫化メチルの除去率は約 1.5 倍, 二硫化 メチルの除去率は約 1.2 倍となりオガクズ混合の 効果が見られた。また，堆肥十オガクズ区の方が 除去率の標準偏差む小さくなった。

図 1 に実験の前後での脱臭槽のアンモニア態窒 素, 硝酸態窒素, $\mathrm{pH}, \mathrm{EC}$ の変化を示す。両試験区 と屯, 実験の開始時より屯終了時の方が窒素成分
が上昇した。特に硝酸態窒素が両試験区で約 1.6 倍に増加したことにより, 脱臭資材内部で硝化が 起こったことが示唆された。 $\mathrm{pH}$ はほとんど変化 しなかったが， EC は両試験区とも上昇した。水 分については, 堆肥区と堆肥十オガクズ区で開始 時がそれぞれ 39.4\%，39.3\% であり，終了時でそ れぞれ $45.2 \% ， 43.1 \%$ であり，両試験区と屯水分 が上昇した。

\section{考察}

本実験の結果により豚ふん堆肥を利用した堆肥 脱臭を行う際に，豚ふん堆肥にオガクズを混合す ることによって硫黄化合物の除去率向上に効果が あることが確認された。あとあとオガクズは臭気 の吸着能力を持ち, 農家段階ではオガクズ脱臭装 置が設置されているところあある。本実験では才 ガクズの混合により豚ふん堆肥の硫黄化合物の吸 着を補うことができたと考えられた。また，アン モニアの除去率は両試験区ともほとんど変わらな かったことから，本実験に打ける程度のアンモ二 アの負荷であれば，水分が約 $40 \%$ 以上であれば 堆肥のみでも除去が可能であると考えられた。ア ンモニアは非常に水に溶解しやすく, 水洗浄によ る脱臭なども行われる ${ }^{8)}$ 。なお，実験の前後で脱 臭槽中の水分が増加したがこれは鶏ふんから蒸発 した水分が脱臭槽中に移行したものと考えられ た。

両試験区で硝酸態窒素の増加が見られたことか ら, 豚ふん堆肥脱臭を行う際には堆肥中で硝酸菌 と巠硝酸菌の活動が起こり,さらに, オガクズ混 合が硝酸菌，亜硝酸菌の活動に悪影響を与えるこ とはないことが示唆された。脱臭槽中の硝酸態窒

表 1.オガクズ混合による豚ふん堆肥の脱臭能力の向上効果

Table 1. The effect of mixed sawdust in swine manure compost deodorization

\begin{tabular}{l|c|c|c}
\hline \hline & 脱臭前濃度 & 堆肥区除去率 $(\%)$ & 堆肥十オガクズ区除去率 $(\%)$ \\
\hline \hline アンモニア $(\mathrm{n}=9)$ & $60 \sim 510 \mathrm{ppm}$ & $99.7 \pm 0.6$ & $100.0 \pm 0.0$ \\
メチルメルカプタン $(\mathrm{n}=6)$ & $0.01 \sim 0.13 \mathrm{ppm}$ & $86.9 \pm 13.4$ & $93.3 \pm 9.0$ \\
硫化メチル $(\mathrm{n}=6)$ & $0.05 \sim 0.43 \mathrm{ppm}$ & $49.0 \pm 46.0$ & $75.8 \pm 30.3$ \\
二硫化メチル $(\mathrm{n}=6)$ & $0.01 \sim 0.04 \mathrm{ppm}$ & $75.7 \pm 22.7$ & $92.8 \pm 9.1$ \\
\hline
\end{tabular}



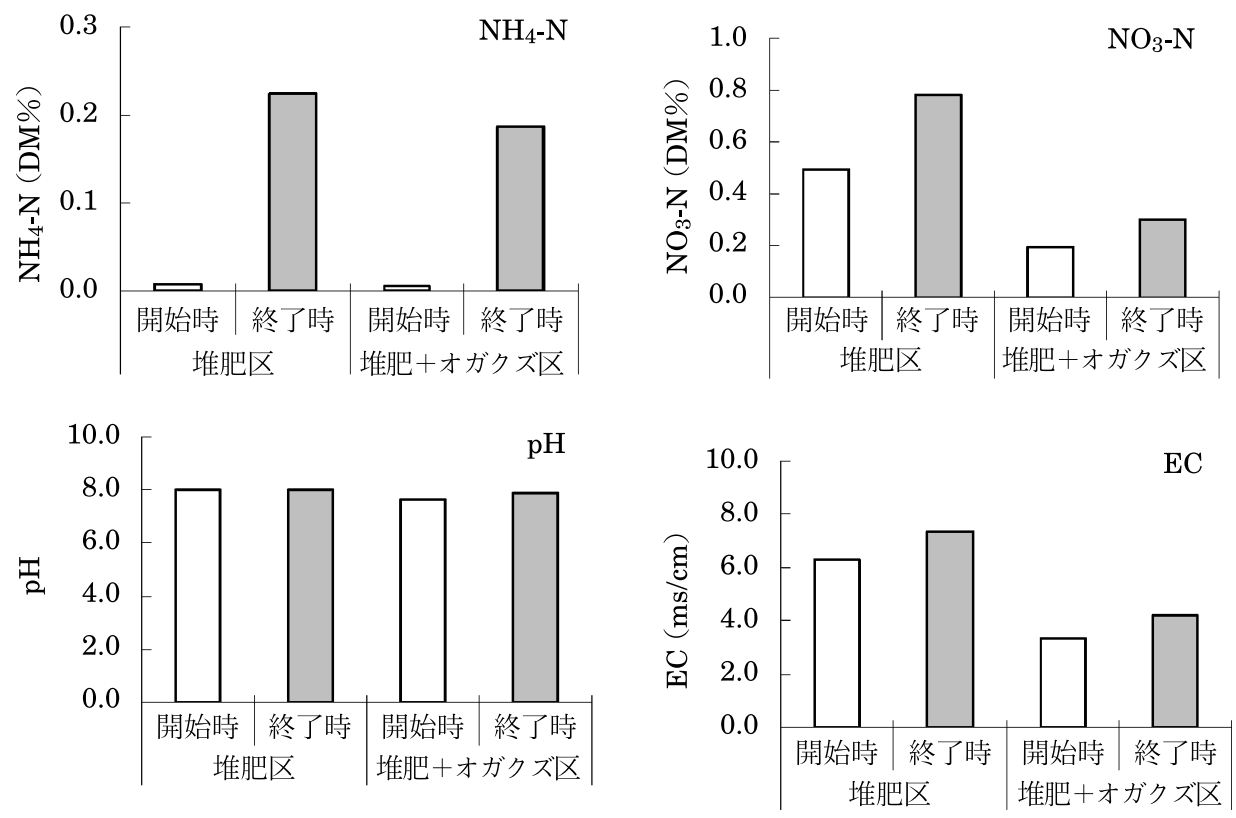

図 1. 実験前後での脱臭槽の $\mathrm{NH}_{4}-\mathrm{N}, \mathrm{NO}_{3}-\mathrm{N}, \mathrm{pH}, \mathrm{EC}$ の変化

Fig. 1. Changes of $\mathrm{NH}_{4}-\mathrm{N}, \mathrm{NO}_{3}-\mathrm{N}, \mathrm{pH}$ and $\mathrm{EC}$ in experimental deodorization apparatus

素が増加したということは，堆肥脱臭は臭気を堆 肥に吸着させる吸着脱臭の面を持つと同時に生物 脱臭としての能力む持つことを示す。また, 脱臭槽 中の $\mathrm{EC}$ の上昇はアンモニア態窒素や硝酸態窒素 の増加に起因すると考えられた。堆肥中の微生物 は乾燥に弱く $40 \%$ 以下では増殖が抑制される ${ }^{9)}$ 。 従って, 堆肥脱臭を行う際には微生物の活性を維 持するために水分を $40 \%$ 以上に維持することが 必要であると考えられる。本多ら ${ }^{10)}$ はオガクズ脱 臭装置では硝化作用は起こらず，脱臭槽から硝酸 菌や亜硝酸菌は検出されなかったとしていること から, 堆肥十オガクズ区では堆肥由来の微生物が 脱臭槽中で働いたものと考えられた。

以上の結果加豚ふ九堆肥脱臭の可能性につい て, アンモニアのみの除去では豚ふん堆肥のみで あ可能であるがオガクズを混合すれば硫黄化合物 の除去も可能であること, 豚ふん堆肥脱臭は生物 脱臭の側面む持つことが確認された。今後は豚ふ ん堆肥脱臭の脱臭機序の解明と実用化に向けて更 なる検討を進めていく予定である。
謝辞

本試験を実施するに際し実験補助として当場の 滝本勝彦技術員に多大なご協力を頂きました。ま た, 九州沖縄農業研究センターの田中章浩主任研 究員之薬師堂謙一バイオマス利用研究利用チーム 長に技術的な示唆を頂きました。この場を借りて 深謝いたします。

\section{文献}

1）田中 博 $\cdot$ 中嶋吉郎 $\cdot$ 代永道裕・羽賀清典 : 豚了几通風堆肥化時に発生する臭気成分之 その脱臭法, 農林漁業における環境保全的 技術に関する総合研究試験成績書, 6, 603606，農林水産技術会議事務局， 1979 .

2）八木広幸・黒田和孝・羽賀清典 : 堆肥の表 面散布による貯留豚ふんの臭気抑制, 日畜 学会 97 回大会講要，91，2000

3) Tanaka, H., K. Kuroda and M. Yonaga : Biological Removal of VFA from Animal Wastes, Anim. Sci. Technol., 63, 5459, 1992. 
4）田中章浩・薬師堂謙一・山本克己 : 堆肥の 悪臭吸着能を活用した堆肥化過程における 悪臭低減化技術, 九州沖縄農業研究成果情 報，15（上）１91-192，2000。

5）道宗直昭：「設備・装置による脱臭技術」, 家畜ふん尿処理・利用の手引き，104-114， (財)畜産環境整備機構, 東京, 1998.

6）悪臭法令研究会 : 四訂版ハンドブック悪臭 防止法, 272-283, ぎょうせい, 東京, 2000 .

7）日本土䗙協会編: 堆肥等有機物分析法, 14-
42，146-154，日本土壌協会，東京，2000.

8）小松 繁:「洗浄法: 分類之原理」, 普及版 防脱臭技術集成，173-183，NTS，東京， 2002.

9）羽賀清典 :「堆肥化の原理と方法」，畜産環 境対策大事典, 第 2 版, 53-59, 農産漁村文 化協会，東京， 2004 .

10）本多勝男 - 宮崎光加 - 米持勝利 : オガ屑脱 臭槽における密閉強制発酵機排ガスの脱臭 試験，神奈川畜試研報，83，64-70，1993. 